\title{
Expression of estrogen and androgen receptors in differentiated thyroid cancer: an additional criterion to assess the patient's risk
}

\author{
Flavia Magri, Valentina Capelli, Mario Rotondi, Paola Leporati, Luigi La Manna ${ }^{1}$, \\ Rubina Ruggiero ${ }^{1}$, Alberto Malovini', Riccardo Bellazzi ${ }^{3}$, Laura Villani ${ }^{4}$ and \\ Luca Chiovato
}

\author{
Units of Internal Medicine and Endocrinology, Fondazione Salvatore Maugeri IRCCS, University of Pavia, 27100 Pavia, Italy \\ ${ }^{1}$ Department of General and Mininvasive Surgery and ${ }^{2}$ Laboratorio di Informatica e Sistemistica per la Ricerca Clinica, Fondazione \\ Salvatore Maugeri IRCCS, 27100 Pavia, Italy \\ ${ }^{3}$ Laboratorio di Informatica Biomedica, Dipartimento di Ingegneria Industriale e dell'Informazione, Università di Pavia, \\ 27100 Pavia, Italy \\ ${ }^{4}$ Units of Pathology and Cytology, Fondazione Salvatore Maugeri IRCCS, University of Pavia, 27100 Pavia, Italy \\ (Correspondence should be addressed to L Chiovato; Email: luca.chiovato@fsm.it)
}

\begin{abstract}
Estrogen receptor (ER) and androgen receptor (AR) may be expressed in thyroid tumors, but their prognostic role is controversial. We investigated whether ER and AR expressions could confer a more aggressive phenotype to thyroid tumors. We enrolled 91 patients ( 13 males and 78 females, mean age $49.3 \pm 14.8$ years) bearing small ( $T 1$ in the 2006 TNM system) differentiated thyroid cancers (DTC). Thirty-eight tumors were incidental histological findings. Using immunohistochemistry, we evaluated $\mathrm{ER} \alpha, \mathrm{ER} \beta$, and $\mathrm{AR}$ expressions in tumors and in its correspondent extra-tumor parenchyma. In tumors, $13(16.7 \%)$ women and one $(7.7 \%)$ man expressed ER $\alpha ; 42$ (53.8\%) women and six (46\%) men expressed ER $\beta$; and $16(20.5 \%)$ women and three $(23.1 \%)$ men expressed AR. In normal thyroid parenchymas, ER $\beta$ was expressed in $52(66.7 \%)$ women and nine $(69.2 \%)$ men, ER $\alpha$ in three (3.8\%) women, and AR in $13(16.7 \%)$ women. Compared with normal thyroid parenchyma, tumors gained ER $\alpha$ and lost ER $\beta$ expressions. Incidental cancers were more commonly $\mathrm{ER} \alpha(-)$ than $\mathrm{ER} \alpha(+)(47.7$ vs $14.3 \%, P=0.037)$. Postsurgical serum thyroglobulin was higher in $\mathrm{ER} \alpha(+)$ tumors than in the $\mathrm{ER} \alpha(-)$ tumors $(P=0.04)$. $\mathrm{ER} \beta(-)$ tumors showed vascular invasion more frequently than the $E R \beta(+)$ tumors $(26.2$ vs $4.1 \%, P=0.005)$. $\mathrm{AR}(+)$ tumors showed capsular invasion more frequently than the $\mathrm{AR}(-)$ tumors $(77.8$ vs $46.6 \%$, $P=0.014)$. In conclusion, ER $\alpha$ positivity, ER $\beta$ negativity, and AR expressions are associated with a more aggressive phenotype of small T1-DTC. ER and AR expressions may represent an additional criterion in deciding whether to perform radioiodine ablation in these tumors.
\end{abstract}

Endocrine-Related Cancer (2012) 19 463-471

\section{Introduction}

Steroid hormones (SHs) are an important class of cell regulators (Kumar \& Thompson 1999, Simoncini \& Genazzani 2003). Their biological effects are mediated by a wide spectrum of ligand-dependent intracellular transcription factors (the SH receptors (SHRs)), which include estrogen receptor (ER), androgen receptor (AR), progesterone receptor, glucocorticoid receptor, and mineralocorticoid receptor (Stanisic et al. 2010).
A role for SHs in the development and progression of human cancer has been observed, each $\mathrm{SH}$ being involved in a specific subset of neoplasm (Ahmad \& Kumar 2011). Cumulative exposure to estrogens plays a role in the development, growth, and progression of breast cancer (Badve \& Nakshatri 2009), while androgens are essential for the initiation and progression of prostate cancer (Heinlein \& Chang 2004). SHRs and their ligands may also be involved in the 
development of other types of neoplasm, such as colon, lung, and thyroid cancers (Ahmad \& Kumar 2011).

Differentiated thyroid cancer (DTC) displays a relevant gender disparity being three times less frequent in men than in women, who are often diagnosed with thyroid cancer in their premenopausal age (Jemal et al. 2010). Estrogen-progesterone therapy was suggested as a risk factor in the development of thyroid neoplasm (Persson et al. 1996) and, at least in one study, thyroid cancer diagnosed during pregnancy or in the early postpartum period was reported to have a worse prognosis (Vannucchi et al. 2010). In spite of this evidence, the epidemiological relationship between thyroid cancer and women's reproductive life remains unclear due to the great variability observed among different ethnic groups (Mack et al. 1999, Negri et al. 1999, Pham et al. 2009).

Both the $\alpha$ and $\beta$ subtypes of ER have been demonstrated in normal and tumor thyroid tissues (Manole et al. 2001, Lee et al. 2005). The level of ER expressions differs in normal compared with tumor tissue and among different histotypes of thyroid tumors (Zeng et al. 2007, 2008). Well-DTC are more often $\mathrm{ER}(+)$ and have a higher degree of ER expressions compared with the undifferentiated or anaplastic cancers (Tavangar et al. 2007, Zeng et al. 2008). Compared with normal thyroid parenchyma, ER $\alpha$ expression is usually increased in thyroid cancers, while ER $\beta$ expression is decreased (Chen et al. 2008). In vitro stimulation of benign and malignant thyroid cells with $17 \beta$-estradiol $\left(\mathrm{E}_{2}\right)$ results in an increased proliferation rate, which is more evident in tumor cells (Manole et al. 2001, Lee et al. 2005). The proliferation of thyroid cancer cells appears to be dependent on $\mathrm{ER} \alpha$-mediated pathways, because it is increased by selective ER $\alpha$ agonists and reduced by ER $\beta$ agonists (Chen et al. 2008). In cultured papillary thyroid cancer cells, $\mathrm{E}_{2}$ treatment does increase ER $\alpha$ expression but not ER $\beta$ levels (Zeng et al. 2008). More importantly, $\mathrm{E}_{2}$-stimulated thyroid cancer cell lines may acquire mitogenic, migratory, and invasive properties, which are typical of a metastatic phenotype (Rajoria et al. 2010). Despite this in vitro evidence, the in vivo oncogenic role of ERs remains controversial. To date, studies on ERs status in thyroid cancers did not reveal significant differences in relation to age, histotype, or tumor stage (Kansakar et al. 2009). As a consequence, their role in thyroid carcinogenesis is still controversial.

Only few data are available regarding the expression of ARs and their role in thyroid cells. The presence of ARs was demonstrated both in normal and in tumor thyroid tissues, with variable degrees of expression
(Zhai et al. 2003). Papillary and follicular cancer cell lines undergoing testosterone stimulation display an upregulation of ARs (Banu et al. 2001) and a tendency to proliferate (Banu et al. 2002). More recently, Banu et al. found a varying pattern of testosterone level and AR status in thyroid tissues of men and women possibly predisposing to the gender-specific incidence of thyroid tumors (Stanley et al. 2012). No data are currently available on the phenotype of $\mathrm{AR}(+)$ thyroid cancer.

Despite these data, ERs and ARs are not mentioned in the more recent guidelines for the diagnosis and management of DTC (Cooper et al. 2009). This may be due to inconclusive data regarding the clinical implications of ER and AR expressions in thyroid tumors. Even if many advances in the diagnosis and management of DTC have been made, the debate is still open in many areas, including the indication for postsurgical radioiodine (RAI) ablation treatment in small DTCs. To date, RAI ablation is not recommended for patients with unifocal cancer $<1 \mathrm{~cm}$ or multifocal cancer when all foci are $<1 \mathrm{~cm}$ in the absence of other higher risk features. Even for 1-4 cm tumors, RAI ablation is recommended in selected patients, who have an intermediate or a high risk for recurrence or death. These higher risk categories are defined as microscopic or macroscopic invasion of tumor into the perithyroidal soft tissues at initial surgery, cervical lymph node metastases, tumor with aggressive histology (such as tall cell, columnar, insular, and solid variants, as well as poorly DTC), vascular invasion, incomplete tumor resection, and distant metastases. According to these recommendations, the majority of currently detected thyroid cancers, mainly T1, smaller than $2 \mathrm{~cm}$ in size, will not receive RAI ablation treatment. A main limitation of the currently used risk stratification schemes is that they do not take into account the prognostic implications of the molecular characteristics of the primary tumor. A possible role for ERs and ARs could be hypothesized in this area.

Moving from the above considerations, we retrospectively evaluated the expression of ERs and ARs in surgical specimens of a large series of $\mathrm{T} 1$ thyroid tumors and in the correspondent extra-tumor parenchyma. We searched for a correlation between ER and AR expressions, on one side, and both the histological phenotype of the tumor and the clinical features of patients, on the other side. The hypothesis to be tested was whether the expression of sex steroid receptors could confer a more aggressive phenotype to thyroid tumors. 


\section{Subjects and methods}

\section{Patients}

The study group included 91 patients (13 males and 78 females, age $20-83$ years, mean $49.3 \pm 14.8$ s.D.) who were diagnosed by histology with a DTC of $<2 \mathrm{~cm}$ in size (T1 according to the 2006 revision of the TNM staging system). In the female subgroup, 37 patients (47.4\% of the women studied) were diagnosed in their premenopausal age. Postmenopausal hormone replacement therapy was considered as an exclusion criterion.

Before surgery, all patients underwent a complete thyroid work-up, which included personal and family history of thyroid diseases and/or autoimmune disorders; clinical examination; and laboratory tests for serum-free thyroxine $\left(\mathrm{FT}_{4}\right)$, free tri-iodothyronine $\left(\mathrm{FT}_{3}\right), \mathrm{TSH}$, thyroid antibodies (thyroglobulin antibody (TG-Ab), thyroperoxidase antibody (TPO-Ab), and TSH receptor antibody (TRAb)), and calcitonin. A standardized thyroid ultrasound (US) scan was also performed with the estimation of thyroid gland volume, echogenicity of the parenchyma, thyroid blood flow, and US characteristics of any nodule. All nodules $>1 \mathrm{~cm}$ in diameter or with suspicious ecographic features were submitted to fine-needle aspiration cytology (FNAC). Fifty-three patients underwent surgery for known malignant or suspicious nodules as assessed by FNAC. In the remaining 38 patients, indications for thyroid surgery were large multi-nodular goiters with compressive symptoms $(n=28)$, Graves' disease $(n=5)$, and toxic adenoma $(n=5)$. In the latter group, the tumor was an incidental finding being detected by histology. When lobectomy only had been performed, it was followed by total thyroidectomy. After total thyroidectomy, which was performed in all cases, patients were treated with $\mathrm{L}_{-} \mathrm{T}_{4}$ at $\mathrm{TSH}-$ suppressive doses. Thyroid hormone profile, serum $\mathrm{Tg}$, and $\mathrm{TgAb}$ were checked on day 45 post-surgery.

Data relative to follow-up (postsurgical thyroglobulin and RAI ablation) were evaluated only in patients with a follow-up longer than 1 year $(n=63)$.

All patients gave their informed consent concerning the future use of clinical and pathological data for research purposes, in accordance with the Institutional Ethics Committee on human experimentation.

\section{Laboratory assays}

Serum concentrations of $\mathrm{FT}_{4}$ (normal range: 8.0 $19.0 \mathrm{pg} / \mathrm{ml}$ ), $\mathrm{FT}_{3}$ (normal range: $1.8-4.2 \mathrm{pg} / \mathrm{ml}$ ), TSH (normal range: $0.4-4.0 \mathrm{mIU} / \mathrm{l}$ ), and $\mathrm{Tg}$ (functional sensitivity, $0.36 \mathrm{ng} / \mathrm{ml}$; Giovanella et al. 2007) were measured using immunochemiluminescent assays by an automated analyzer (Immulite 2000; DPC Cirrus, Los Angeles, CA, USA) using commercial kits (Diagnostic Products Corporation, Los Angeles, CA, USA). Serum concentrations of TG-Ab (normal range: $<60 \mathrm{U} / \mathrm{ml}$ ) and TPO-Ab (normal range: $<60 \mathrm{U} / \mathrm{ml}$ ) were measured using immunochemiluminescent assays using commercial kits (Brahms, Hennigsdorf, Germany). TRAbs were measured using a secondgeneration human TSH receptor assay (LIA TRAK human; Brahms) with a sensitivity of $1.0 \mathrm{U} / 1$.

\section{Surgical samples' immunohistochemistry and assessment of SHR expressions}

From the formalin-fixed, paraffin-embedded tumor specimens, sections were obtained and observed at light microscope. Tumors were investigated for size, histotype, tumor capsule, thyroid capsule or vessels invasion, necrosis, psammoma bodies, and grade of differentiation. Histological examination was performed in double blind by two expert pathologists. Tumors being detected by histology after thyroidectomy for benign diseases were defined as incidental carcinomas. Four micron-thick tissue sections, each of them including the tumor area and the normal surrounding thyroid tissue, were immunostained for $\mathrm{ER} \alpha, \mathrm{ER} \beta$, and AR. In order to unveil specific epitopes, tissue samples were pretreated in a pressure cooker for $10 \mathrm{~min}$ at $121{ }^{\circ} \mathrm{C}$. After cooling to room temperature, slide-mounted tissue sections were incubated with a monoclonal mouse antihuman ER $\alpha$ antibody (clone 1D5, DakoCytomation; DAKO-Italia, Milan, Italy) diluted 1:40, a monoclonal mouse antihuman ER $\beta$ antibody (clone PPG5/10, DakoCytomation, DAKO-Italia) diluted 1:20, and a monoclonal mouse antihuman AR antibody (clone AR441, DakoCytomation; DAKO-Italia) diluted 1:50. The immunocytochemical staining was performed using the automated DakoCytomation Autostainer platform. To minimize nonspecific staining, the optimal working dilution of each antibody was determined using positive and negative control tissues such as breast and prostate cancers. Only cells showing a nuclear staining were considered positive for ERs or ARs respectively. Scoring of immunoreactivity of ER $\alpha$, $\mathrm{ER} \beta$, and AR expressions in tumor and normal cells was performed on high-power field $(\times 440)$ using a standard light microscope. The examination field was simultaneously evaluated by two pathologists using a double-headed microscope. Interobserver differences were $<1 \%$. Immunohistochemistry results were scored as follows: 0 , negative; $1,<30 \% ; 2,30-60 \%$; and $3,>60 \%$. 
Table 1 Histopathological characteristics of thyroid cancers

\begin{tabular}{|c|c|c|c|c|}
\hline & $\begin{array}{l}\text { Whole group } \\
\quad(n=91)\end{array}$ & $\begin{array}{l}\text { Male subgroup } \\
\qquad(n=13)\end{array}$ & $\begin{array}{l}\text { Female subgroup } \\
\qquad(n=78)\end{array}$ & $\begin{array}{c}\text { Male vs } \\
\text { female }(P)\end{array}$ \\
\hline $\begin{array}{l}\text { Tumor size (mean } \pm \text { s.D.), whole } \\
\text { group }\end{array}$ & $9.4 \pm 4.5$ & $10.5 \pm 4.2$ & $9.2 \pm 4.6$ & 0.362 \\
\hline Incidental tumors $(n(\%))$ & $38(41.8 \%)$ & $5(38.5 \%)$ & $33(42.3 \%)$ & 1.0 \\
\hline $\begin{array}{l}\text { Tumor size (mean } \pm \text { S.D.), } \\
\text { incidental group }\end{array}$ & $7.4 \pm 4.2$ & $9.6 \pm 6.1$ & $7 \pm 3.8$ & 0.211 \\
\hline Multifocal tumors & $24(26.4 \%)$ & $3(23.0 \%)$ & $21(26.9 \%)$ & 1.0 \\
\hline Capsule invasion & $48(52.7 \%)$ & $9(69.2 \%)$ & $39(50.0 \%)$ & 0.241 \\
\hline Vascular invasion & $13(14.3 \%)$ & $1(7.7 \%)$ & $12(15.4 \%)$ & 0.409 \\
\hline $\begin{array}{l}\text { Degree of differentiation } \\
\text { (poor/intermediate/good) }\end{array}$ & 4/67/20 (4.4/73.6/22\%) & $0 / 9 / 4(0 / 69.2 / 30.8 \%)$ & $4 / 58 / 16(5.1 / 74.3 / 20.5 \%)$ & 0.727 \\
\hline Classical papillary & $59(64.8 \%)$ & $13(100.0 \%)$ & 46 (59\%) & 0.042 \\
\hline Papillary-follicular variant & $21(23.1 \%)$ & 0 & $21(26.9 \%)$ & NA \\
\hline Papillary sclerosant variant & $7(7.7 \%)$ & 0 & $7(9 \%)$ & NA \\
\hline Pure follicular & $4(4.4 \%)$ & 0 & $4(5.1 \%)$ & NA \\
\hline
\end{tabular}

Data presented, number (\%).

\section{Statistical analysis}

Quantitative values were expressed as mean \pm s.D.s and as median and interquartile range, when data deviated from the normal distribution. Difference between groups was evaluated by the Fisher exact test and two-tailed Wilcoxon test for quantitative variables deviating from the normal distribution. Logistic regression was performed for estimating the relative risk. Statistical analysis was performed using the SPSS Software (SPSS, Inc., Evanston, IL, USA). A $P$ value $<0.05$ was considered statistically significant.

\section{Results}

\section{Histopathological findings and sex steroid receptor expression}

Histological diagnoses and tumor features are summarized in Table 1 . In the whole study group, the mean tumor size was $9.4 \pm 4.5 \mathrm{~mm}$ (s.D.), a significant difference being observed between clinical and incidental tumors $(11.1 \pm 4 \mathrm{~mm}$ vs $7.4 \pm 4.2 \mathrm{~mm}$, $P=0.001)$. More than half of tumor specimens were classical papillary cancers, and their histotype was found in all male patients. The papillary-follicular variant was observed only in the female group. Multifocal cancers were detected in $26.4 \%$ of the specimens. In most cases, thyroid cancers showed a good or intermediate degree of differentiation with no difference between women and men. There were only four cases of poorly DTC, all detected in the female subgroup.

Table 2 shows the pattern of expression of ER $\alpha$, $E R \beta$, and $A R$ in the tumor and in the surrounding normal parenchyma. ER $\alpha$ expression was found in 13 $(16.7 \%)$ tumor specimens in the female subgroup (seven classical papillary and six papillary-follicular variants) and in one (7.6\%) man affected by classical

Table 2 Pattern of expression of estrogen receptor $\alpha(E R \alpha)$, ER $\beta$, and androgen receptor $(A R)$ in the tumor and in the surrounding normal tissue (percentages calculated upon the number of each histotype)

\begin{tabular}{|c|c|c|c|c|c|c|}
\hline & \multicolumn{3}{|c|}{ Tumor } & \multicolumn{3}{|c|}{ Normal surrounding tissue } \\
\hline & $\mathrm{ER} \alpha$ & ER $\beta$ & AR & $\mathrm{ER} \alpha$ & $E R \boldsymbol{\beta}$ & AR \\
\hline \multicolumn{7}{|l|}{ Women } \\
\hline Classical papillary $(n=46)$ & $7(15.2 \%)$ & $25(54.3 \%)$ & $5(10.9 \%)$ & $1(2.2 \%)$ & $31(67.4 \%)$ & $6(13.0 \%)$ \\
\hline Papillary follicular variant $(n=21)$ & $6(28.6 \%)$ & $12(57.1 \%)$ & $8(38.1 \%)$ & $2(9.5 \%)$ & $13(61.9 \%)$ & $6(28.6 \%)$ \\
\hline Papillary sclerosing variant $(n=7)$ & 0 & $4(57.1 \%)$ & $1(14.3 \%)$ & 0 & $6(85.7 \%)$ & $1(14.3 \%)$ \\
\hline Pure follicular $(n=4)$ & 0 & $1(25 \%)$ & $2(50 \%)$ & 0 & $2(50 \%)$ & 0 \\
\hline Total $=78$ & $13(16.7 \%)$ & $42(53.8 \%)$ & $16(20.5 \%)$ & $3(3.8 \%)$ & $52(66.7 \%)$ & $13(16.7 \%)$ \\
\hline \multicolumn{7}{|l|}{ Men } \\
\hline Classical papillary $(n=13)$ & $1(7.7 \%)$ & $6(46.0 \%)$ & $3(23.1 \%)$ & 0 & $9(69.2 \%)$ & 0 \\
\hline \multicolumn{7}{|l|}{ Women + men } \\
\hline Total $=91$ & $14(15.4 \%)$ & 49 (53.8\%) & $19(20.9 \%)$ & $3(3.3 \%)$ & $61(67.0 \%)$ & $13(14.3 \%)$ \\
\hline
\end{tabular}

Data presented, number (\%). 
papillary tumor. $\operatorname{ER} \beta(+)$ tumors were found in 42 $(53.8 \%)$ specimens in the female subgroup (25 classical papillary, 12 papillary-follicular variant, four papillary sclerosing variant, and one pure follicular) and six (46\%) specimens in the male subgroup. The normal thyroid parenchyma expressed $E R \beta$ in $52(66.7 \%)$ women and in nine $(69.2 \%)$ men. $\mathrm{ER} \alpha(+)$ cells in the normal thyroid parenchyma were found in three women $(3.8 \%)$ and in none of the men. AR was expressed in $16(20.5 \%)$ tumor specimens in the female subgroup and in three (23.1\%) specimens in the male subgroup. The pattern of expression of ERs and ARs did not significantly differ in pre- and postmenopausal women. Therefore, they were analyzed as a whole group.

Table 3 shows the changes in expression of ER $\alpha$, $\mathrm{ER} \beta$, and $\mathrm{AR}$ in the tumor compared with the surrounding normal parenchyma. In most $\mathrm{ER} \alpha(+)$ tumors, the receptor was gained with respect to the normal thyroid parenchyma. On the contrary, most tumors lost the expression of ER $\beta$ or their immunoreactivity score was definitely lower when compared with the normal surrounding tissue. Changes in AR expression between tumor and normal parenchyma showed a wide interindividual variability.

Both in the whole group and in the female subgroup, the prevalence of incidental tumors was significantly lower among the $\operatorname{ER} \alpha(+)$ tumors than among the $\mathrm{ER} \alpha(-)$ tumors $(14.3$ and $47.7 \%$ respectively, $P=0.037$; Fig. 1). The percentage of incidental findings did not significantly differ in $\operatorname{ER} \beta(+)$ compared with $\operatorname{ER} \beta(-)$ tumors. Among tumors that gained ER $\alpha$ expression, only $8 \%$ were well differentiated while the prevalence of well-differentiated tumors in the $\mathrm{ER} \alpha(-)$ group was $25 \%(\mathrm{NS})$.

$\operatorname{ER} \beta(-)$ tumors showed histological evidence of vascular invasion in 11 out of $42(26.2 \%)$ specimens as opposed to only two out of $49(4.1 \%) \operatorname{ER} \beta(+)$ specimens. This difference was statistically significant $(P=0.005)$, conferring a relative risk of $1.20(95 \% \mathrm{CI}$ $0.025-0.578 ; P$ value 0.008$)$. Similar results were found in the whole study group and in the female subgroup (Fig. 2).

In the whole study group, $\mathrm{AR}(+)$ tumors showed histological evidence of capsular invasion in a significantly higher percentage than the $\mathrm{AR}(-)$ tumors (77.8 vs $46.6 \%, P=0.014$; Fig. 3 ).

\section{Sex steroid receptor expression and postsurgical serum Tg levels}

Among 63 patients with a follow-up longer than 1 year, 19 patients were treated with thyroidectomy only.

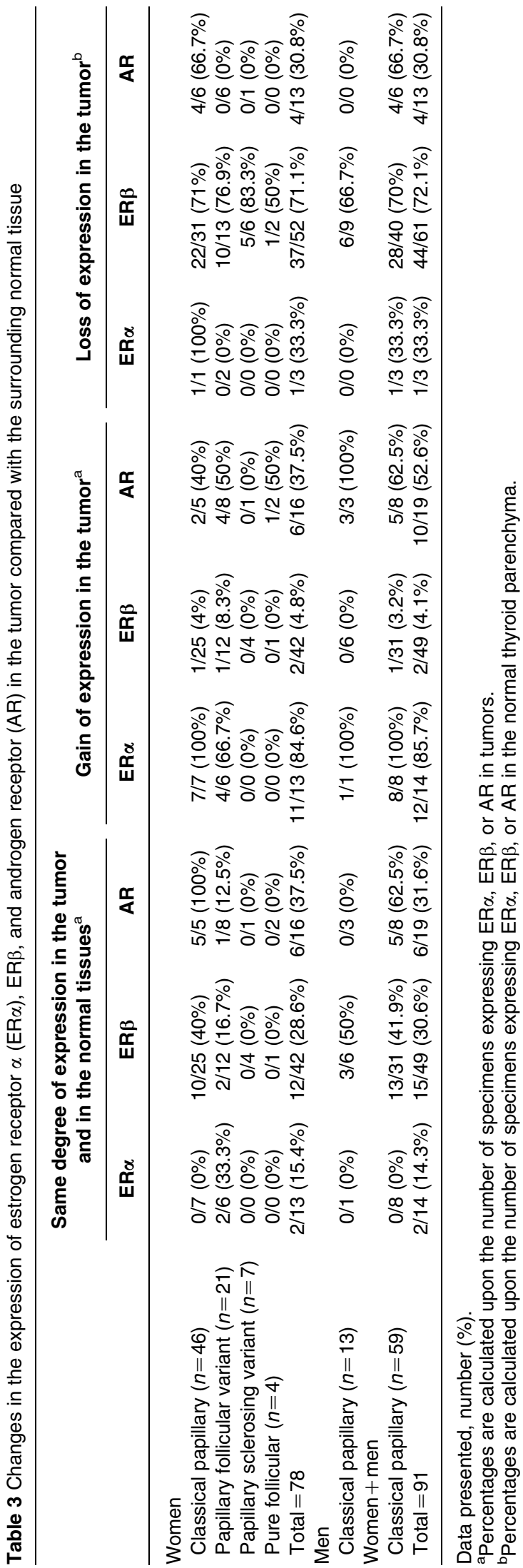




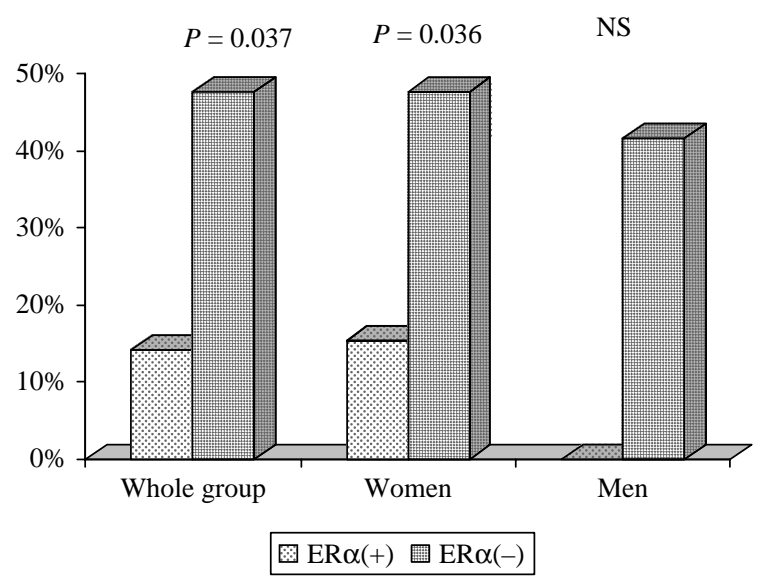

Figure 1 Percentage of tumors presenting as incidental findings at histology in $E R \alpha(+)$ and $E R \alpha(-)$ thyroid cancers. Data are calculated in the whole study group, in the female subgroup, and in the male subgroup (statistically significant differences are shown). NS, not significant.

The remaining 43 patients were submitted to postsurgical RAI ablation, according to the current ATA guidelines at the time of the study (Cooper et al. 2006). One patient was lost to the follow-up after surgery. Thyroglobulin was measured on $\mathrm{L}^{-\mathrm{T}_{4}}$-suppressive therapy 45 days after surgery. In the subgroup of patients treated with thyroidectomy and RAI ablation, the serum levels of thyroglobulin were significantly $(P$ value $=0.043)$ higher in $\operatorname{ER} \alpha(+)(n=11$, median, 1.03; interquartile range (IQR), 0.21-6.65) than in $\mathrm{ER} \alpha(-)(n=32$; median, 0; IQR, 0-1.07) patients. An opposite trend was observed in $\operatorname{ER} \beta(+)$ tumors vs $\operatorname{ER} \beta(-)$ tumors, but the difference did not reach statistical significance.

\section{Discussion}

Consistent with the previous data (Manole et al. 2001, Lee et al. 2005), we found an expression of $\mathrm{ER} \alpha, \mathrm{ER} \beta$, and AR both in normal and in tumor thyroid tissues. We then evaluated the clinical and pathological presentation of small (T1) thyroid tumors in relation to the expression pattern of these sex hormone receptors.

ER $\beta$ expression was partially or totally lost in tumors compared with the correspondent normal surrounding tissue. $\operatorname{ER} \beta(-)$ tumors were more aggressive than the $\operatorname{ER} \beta(+)$ tumors, because at histology they showed a significantly higher prevalence of vascular invasion. This feature was recently indicated as a predictor of distant metastasis in welldifferentiated thyroid carcinomas (Mete \& Asa 2011). Loss of ER $\beta$ was previously described in thyroid (Chen et al. 2008) as well as in prostate and colon cancers, and above all in breast cancer (Bardin et al. 2004). However, a negative relation between ER $\beta$ expression and vascular invasion was previously reported only in breast cancer. These results support the hypothesis that $\operatorname{ER} \beta$ expression has a protective role in the oncogenetic process (Fox et al. 2008), possibly due to ER $\beta$-activated pro-apoptotic pathways (Zeng et al. 2007, 2008).

$\mathrm{ER} \alpha$ expression was acquired or increased in the tumor when compared with the correspondent normal tissue. At diagnosis, a significant majority of $\mathrm{ER} \alpha(+)$ thyroid cancers were clinically evident, being detected before surgery by FNAC. These findings suggest that $\mathrm{ER} \alpha(+)$ thyroid cancers might be more aggressive and are in line with previous in vitro experiments demonstrating that ER $\alpha$-activated pathways are able to enhance cell growth (Clarke 2003) and that ER $\alpha$-selective stimulation promotes thyroid cell proliferation (Zeng et al. 2007, 2008). The finding that $\operatorname{ER} \alpha(+)$ tumors were more frequently nonincidental is particularly relevant because previous studies indicated that non-incidentally discovered papillary thyroid microcarcinomas (i.e. papillary carcinomas $<1.5 \mathrm{~cm}$ in size) are at increased risk of persistent/relapsing disease (Pellegriti et al. 2004, Pisanu et al. 2009). In our series, $\mathrm{ER} \alpha(+)$ patients also had higher serum levels of postsurgical $\mathrm{Tg}$ while on $\mathrm{L}^{-\mathrm{T}_{4}}$ therapy. Although not considered a sensitive marker, a higher postsurgical serum $\mathrm{Tg}$ might indicate a less favorable prognosis (Lin et al. 2002, Brassard et al. 2011). The carcinogenetic role of $E R \alpha$ is well established in breast tumors (Clemons \& Goss 2001), but it is now considered relevant also in lung (Rades

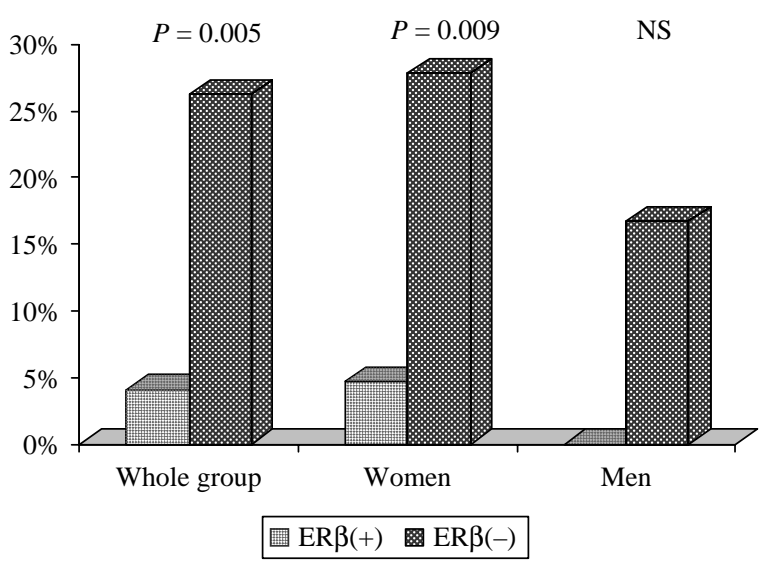

Figure 2 Percentage of tumors with histological evidence of vascular invasion in $\operatorname{ER} \beta(+)$ and $\operatorname{ER} \beta(-)$ thyroid cancers. Data are calculated in the whole study group, in the female subgroup, and in the male subgroup (statistically significant differences are shown). NS, not significant. 


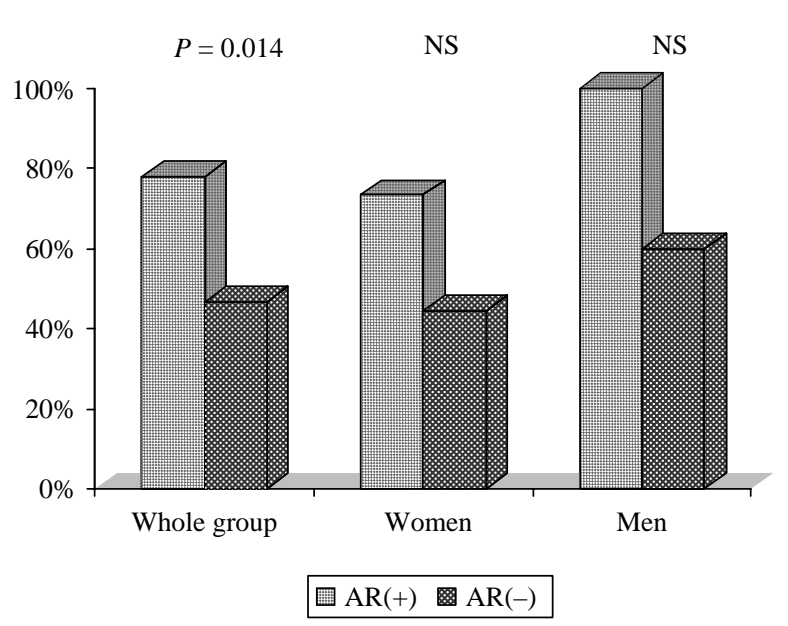

Figure 3 Percentage of tumors with histological evidence of capsular invasion in $\mathrm{AR}(+)$ and $\mathrm{AR}(-)$ thyroid cancers. Data are calculated in the whole study group, in the female subgroup, and in the male subgroup (statistically significant differences are shown). NS, not significant.

et al. 2012), colon (Barone et al. 2012), and other types of neoplasms.

AR expression was less common, and its gradient of expression between tumor and normal parenchyma was more variable. $\mathrm{AR}(+)$ tumors were more aggressive than the $\mathrm{AR}(-)$ tumors, due to a significantly increased prevalence of capsular invasion. These data are of particular interest because a recent study investigating papillary microcarcinomas demonstrated that capsular invasion is an independent factor significantly increasing the risk of nodal metastasis (Pisanu et al. 2009). Overall, our results strongly suggest that the pattern of ER and AR expressions could be used as a tool to identify high-risk patients with T1-DTC and to decide which of them would deserve postsurgical RAI ablation.

In thyroid cell lines, $\mathrm{ER} \alpha$ and $\mathrm{AR}$ have been reported to be upregulated by $\mathrm{E}_{2}$ and testosterone respectively (Banu et al. 2001, 2002, Zeng et al. 2007, 2008). Studies concerning the expression pattern of ERs in vivo are still scarce. In medullary thyroid cancer and C-cells hyperplasia, AR expression was found to be increased in male patients (Zhai et al. 2003). Moreover, $A R$ mRNA expression was found to be increased in a majority of men and decreased in a majority of women, also in a series of non-medullary thyroid carcinomas (Stanley et al. 2012). In our series of DTC, the ER and AR expression patterns did not significantly differ when considering men, premenopausal women, or postmenopausal women. The discrepancy with in vitro data might be attributed to the different experimental conditions, i.e. acute in vitro exposure to a constant hormonal stimulus compared with chronic in vivo exposure to fluctuant sex steroid concentrations. Owing to the lack of data on circulating levels of estrogens and androgens in patients at the time of surgery, we cannot exclude the role of these hormones in modulating the expression of ERs and ARs in thyroid tissue.

The effects of ERs on different molecular pathways involved in growth and function of the thyroid gland have recently been reviewed. The authors hypothesized a potential new avenue and clinical utility for ERs as a target for prevention and treatment of thyroid cancers (Rajoria et al. 2011). Future studies will be needed to further investigate this possibility.

In conclusion, our data, obtained in a large series of T1-DTC, showed that ER $\alpha$ positivity, ER $\beta$ negativity, and AR expression are associated with a more aggressive phenotype. The expression pattern of estrogen and ARs may represent an additional criterion to be considered in the assessment of the patient's risk and in the decision about performing a postsurgical treatment with RAI of T1-DTC.

\section{Declaration of interest}

The authors declare that there is no conflict of interest that could be perceived as prejudicing the impartiality of the research reported.

\section{Funding}

This research did not receive any specific grant from any funding agency in the public, commercial or not-for-profit sector.

\section{Acknowledgements}

The authors would like to thank the technical staff of the Unit of Pathology and Cytology, Fondazione Salvatore Maugeri IRCCS, Pavia, Italy.

\section{References}

Ahmad N \& Kumar R 2011 Steroid hormone receptors in cancer development: a target for cancer therapeutics. Cancer Letters 300 1-9. (doi:10.1016/j.canlet.2010.09. 008)

Badve S \& Nakshatri H 2009 Oestrogen-receptor-positive breast cancer: towards bridging histopathological and molecular classifications. Journal of Clinical Pathology 62 6-12. (doi:10.1136/jcp.2008.059899)

Banu KS, Govindarajulu P \& Aruldhas MM 2001 Testosterone and estradiol have specific differential modulatory effect on the proliferation of human thyroid 
papillary and follicular carcinoma cell lines independent of TSH action. Endocrine Pathology 12 315-327. (doi:10.1385/EP:12:3:315)

Banu SK, Govindarajulu P \& Aruldhas MM 2002 Testosterone and estradiol differentially regulate TSH-induced thyrocyte proliferation in immature and adult rats. Steroids 67 573-579. (doi:10.1016/S0039128X(02)00008-9)

Bardin A, Boulle N, Lazennec G, Vignon F \& Pujol P 2004 Loss of ERbeta expression as a common step in estrogendependent tumor progression. Endocrine-Related Cancer 11 537-551. (doi:10.1677/erc.1.00800)

Barone M, Lofano K, De Tullio N, Licino R, Albano F \& Di Leo A 2012 Dietary, endocrine, and metabolic factors in the development of colorectal cancer. Journal of Gastrointestinal Cancer 43 13-19. (doi:10.1007/s12029011-9332-7)

Brassard M, Borget I, Edet-Sanson A, Giraudet AL, Mundler O, Toubeau M, Bonichon F, Borson-Chazot F, Leenhardt L, Schvartz C et al. 2011 Long-term follow-up of patients with papillary and follicular thyroid cancer: a prospective study on 715 patients. Journal of Clinical Endocrinology and Metabolism 96 1352-1359. (doi:10.1210/jc.20102708)

Chen GG, Vlantis AC, Zeng Q \& van Hasselt CA 2008 Regulation of cell growth by estrogen signaling and potential targets in thyroid cancer. Current Cancer Drug Targets 8 367-377. (doi:10.2174/156800908785133150)

Clarke RB 2003 Steroid receptors and proliferation in the human breast. Steroids 68 789-794. (doi:10.1016/S0039128X(03)00122-3)

Clemons M \& Goss P 2001 Estrogen and the risk of breast cancer. New England Journal of Medicine 344 276-285. (doi:10.1056/NEJM200101253440407)

Cooper DS, Doherty GM, Haugen BR, Kloos RT, Lee SL, Mandel SJ, Mazzaferri EL, McIver B, Sherman SI, Tuttle RM et al. 2006 Management guidelines for patients with thyroid nodules and differentiated thyroid cancer. Thyroid 16 109-142. (doi:10.1089/thy.2006.16.109)

Cooper DS, Doherty GM, Haugen BR, Kloos RT, Lee SL, Mandel SJ, Mazzaferri EL, McIver B, Pacini F, Schlumberger M et al. 2009 Revised American Thyroid Association management guidelines for patients with thyroid nodules and differentiated thyroid cancer. Thyroid 19 1167-1214. (doi:10.1089/thy.2009.0110)

Fox EM, Davis RJ \& Shupnik MA 2008 ERbeta in breast cancer - onlooker, passive player, or active protector? Steroids 73 1039-1051. (doi:10.1016/j.steroids.2008.04. 006)

Giovanella L, Ceriani L \& Ghelfo A 2007 Redefining functional sensitivity of thyroglobulin assay on Immulite platform: implications in thyroid cancer management. Clinical Chemistry and Laboratory Medicine $\mathbf{4 5}$ 1523-1524. (doi:10.1515/CCLM.2007.309)

Heinlein CA \& Chang C 2004 Androgen receptor in prostate cancer. Endocrine Reviews 25 276-308. (doi:10.1210/er. 2002-0032)
Jemal A, Siegel R, Xu J \& Ward E 2010 Cancer statistics, 2010. CA: A Cancer Journal for Clinicians 60 277-300. (doi:10.3322/caac.20073)

Kansakar E, Chang YJ, Mehrabi M \& Mittal V 2009 Expression of estrogen receptor, progesterone receptor, and vascular endothelial growth factor-A in thyroid cancer. American Surgeon 75 785-789 (discussion 789).

Kumar R \& Thompson EB 1999 The structure of the nuclear hormone receptors. Steroids 64 310-319. (doi:10.1016/ S0039-128X(99)00014-8)

Lee ML, Chen GG, Vlantis AC, Tse GM, Leung BC \& van Hasselt CA 2005 Induction of thyroid papillary carcinoma cell proliferation by estrogen is associated with an altered expression of Bcl-xL. Cancer Journal 11 113-121. (doi:10.1097/00130404-200503000-00006)

Lin JD, Huang MJ, Hsu BR, Chao TC, Hsueh C, Liu FH, Liou MJ \& Weng HF 2002 Significance of postoperative serum thyroglobulin levels in patients with papillary and follicular thyroid carcinomas. Journal of Surgical Oncology 80 45-51. (doi:10.1002/jso.10089)

Mack WJ, Preston-Martin S, Bernstein L, Qian D \& Xiang M 1999 Reproductive and hormonal risk factors for thyroid cancer in Los Angeles County females. Cancer Epidemiology, Biomarkers \& Prevention 8 991-997.

Manole D, Schildknecht B, Gosnell B, Adams E \& Derwahl M 2001 Estrogen promotes growth of human thyroid tumor cells by different molecular mechanisms. Journal of Clinical Endocrinology and Metabolism 86 1072-1077. (doi:10.1210/jc.86.3.1072)

Mete O \& Asa SL 2011 Pathological definition and clinical significance of vascular invasion in thyroid carcinomas of follicular epithelial derivation. Modern Pathology 24 1545-1552. (doi:10.1038/modpathol.2011.119)

Negri E, Dal Maso L, Ron E, La Vecchia C, Mark SD, Preston-Martin S, McTiernan A, Kolonel L, Yoshimoto Y, Jin F et al. 1999 A pooled analysis of case-control studies of thyroid cancer. II. Menstrual and reproductive factors. Cancer Causes \& Control 10 143-155. (doi:10.1023/ A:1008880429862)

Pellegriti G, Scollo C, Lumera G, Regalbuto C, Vigneri R \& Belfiore A 2004 Clinical behavior and outcome of papillary thyroid cancers smaller than $1.5 \mathrm{~cm}$ in diameter: study of 299 cases. Journal of Clinical Endocrinology and Metabolism 89 3713-3720. (doi:10.1210/jc.2003031982)

Persson I, Yuen J, Bergkvist L \& Schairer C 1996 Cancer incidence and mortality in women receiving estrogen and estrogen-progestin replacement therapy - long-term follow-up of a Swedish cohort. International Journal of Cancer 67 327-332. (doi:10.1002/(SICI)10970215(19960729)67:3<327::AID-IJC4 > 3.0.CO;2-T)

Pham TM, Fujino Y, Mikami H, Okamoto N, Hoshiyama Y, Tamakoshi A, Matsuda S \& Yoshimura T 2009 Reproductive and menstrual factors and thyroid cancer among Japanese women: the Japan Collaborative Cohort Study. Journal of Women's Health 18 331-335. (doi:10.1089/jwh.2008.1038) 
Pisanu A, Reccia I, Nardello O \& Uccheddu A 2009 Risk factors for nodal metastasis and recurrence among patients with papillary thyroid microcarcinoma: differences in clinical relevance between nonincidental and incidental tumors. World Journal of Surgery 33 460-468. (doi:10.1007/s00268-008-9870-8)

Rades D, Setter C, Dahl O, Schild SE \& Noack F 2012 The prognostic impact of tumor cell expression of estrogen receptor-alpha, progesterone receptor, and androgen receptor in patients irradiated for non-small cell lung cancer. Cancer 118 157-163. (doi:10.1002/cncr.26282)

Rajoria S, Suriano R, Shanmugam A, Wilson YL, Schantz SP, Geliebter J \& Tiwari RK 2010 Metastatic phenotype is regulated by estrogen in thyroid cells. Thyroid 20 33-41. (doi:10.1089/thy.2009.0296)

Rajoria S, Suriano R, George AL, Shanmugam A, Jussim C, Shin EJ, Moscatello AL, Geliebter J, Carpi A \& Tiwari RK 2011 Estrogen activity as a preventive and therapeutic target in thyroid cancer. Biomedicine \& Pharmacotherapy 66 151-158. (doi:10.1016/j.biopha.2011.11.010)

Simoncini T \& Genazzani AR 2003 Non-genomic actions of sex steroid hormones. European Journal of Endocrinology 148 281-292. (doi:10.1530/eje.0. 1480281)

Stanisic V, Lonard DM \& O'Malley BW 2010 Modulation of steroid hormone receptor activity. Progress in Brain Research 181 153-176.

Stanley JA, Aruldhas MM, Chandrasekaran M, Neelamohan R, Suthagar E, Annapoorna K, Sharmila S, Jayakumar J, Jayaraman G, Srinivasan N et al. 2012 Androgen receptor expression in human thyroid cancer tissues: a potential mechanism underlying the gender bias in the incidence of thyroid cancers. Journal of Steroid Biochemistry and Molecular Biology 130 105-124. (doi:10.1016/j.jsbmb. 2012.02.004)

Tavangar SM, Monajemzadeh M, Larijani B \& Haghpanah V 2007 Immunohistochemical study of oestrogen receptors in 351 human thyroid glands. Singapore Medical Journal 48 744-747.

Vannucchi G, Perrino M, Rossi S, Colombo C, Vicentini L, Dazzi D, Beck-Peccoz P \& Fugazzola L 2010 Clinical and molecular features of differentiated thyroid cancer diagnosed during pregnancy. European Journal of Endocrinology 162 145-151. (doi:10.1530/EJE-09-0761)

Zeng Q, Chen GG, Vlantis AC \& van Hasselt CA 2007 Oestrogen mediates the growth of human thyroid carcinoma cells via an oestrogen receptor-ERK pathway. Cell Proliferation 40 921-935.

Zeng Q, Chen G, Vlantis A, Tse G \& van Hasselt C 2008 The contributions of oestrogen receptor isoforms to the development of papillary and anaplastic thyroid carcinomas. Journal of Pathology 214 425-433. (doi:10.1002/ path.2297)

Zhai QH, Ruebel K, Thompson GB \& Lloyd RV 2003 Androgen receptor expression in C-cells and in medullary thyroid carcinoma. Endocrine Pathology 14 159-165. (doi:10.1385/EP:14:2:159)

Received in final form 18 April 2012

Accepted 24 April 2012 Made available online as an Accepted Preprint 24 April 2012 